\title{
Development of statistical models for trihalomethane (THM) removal in drinking water sources using carbon nanotubes (CNTs)
}

\author{
Kadir Özdemir and Ömer Güngör* \\ Department of Environmental Engineering, Zonguldak Bülent Ecevit University, 67100, Zonguldak, Turkey
}

\begin{abstract}
This research developed models using the multiple linear regression technique for prediction of trihalomethane (THM) removal from chlorinated drinking water sources through a combination of a coagulation process with carbon nanotubes (CNTs). Terkos Lake water (TLW), Buyukçekmece Lake water (BLW) and Ulutan Lake water (ULW) samples were coagulated by a conventional coagulant (alum) and increasing doses of single-walled carbon nanotubes (SWCNTs) and multi-walled carbon nanotubes (MWCNTs) with the addition of alum. Also, chlorination experiments were conducted with water reservoirs from TLW, BLW and ULW, with different water quality regarding bromide concentration and organic matter content. The factors studied affecting THM removal were contact time, chlorine dose, coagulation process, total organic carbon (TOC), and specific ultraviolet absorbance (SUVA). Statistical analysis of the results focused on the development of multiple regression models, as Models 1 and 2, for predicting total trihalomethane (TTHM) based on the use of contact time, SWCNTs and MWCNTs doses, chlorine dose and TOC. When the two models were compared, Model 1 proved best suited to describe THM removal for the three water sources. The developed models provided satisfactory estimations of THM removal; the model regression coefficients for Models 1 and 2 were 0.88 and 0.77, respectively. Furthermore, the root-mean-square error (RMSE) values of 0.083 and 0.126 confirm the reliability of the two models. The results show that THM removal can be simply predicted by using the multiple linear regression technique in chlorinated drinking water sources.
\end{abstract}

Keywords: trihalomethanes, modelling, drinking water, carbon nanotubes (CNTs)

\section{INTRODUCTION}

A significant public health advance, since the turn of the $20^{\text {th }}$ century several methods have been used for disinfection of drinking water, such as chlorination, ozonation, chlorine dioxide, and ultraviolet irradiation. Nevertheless, chlorination is the most widely used method in the world because of its chlorine oxidizing potential and is extremely cost-effective (Elshorbagy et al., 2000; Arora et al., 1997; Krasner et al., 2001).

Although chlorine disinfectant is effective, it interacts with organic precursors in chlorinated water, and thus disinfection by-products (DBP) such as trihalomethanes (THMs), and haloacetic acids (HAAs) form (Elshorbagy et al., 2000; Rook, 1974; Bellar et al., 1974; White, 1992; Rofriguez and Serodes, 2001). Among more than 600 DBPs, trihalomethanes (THMs), i.e., chloroform $\left(\mathrm{CHCl}_{3}\right)$, bromodichloromethane $\left(\mathrm{CHCl}_{2} \mathrm{Br}\right)$, dibromochloromethane $\left(\mathrm{CHBr}_{2} \mathrm{Cl}\right)$, and bromoform $\left(\mathrm{CHBr}_{3}\right)$ have been widely reported in drinking water supplies (Richardson, 1998). Due to the adverse health effects on humans, stringent regulations have been developed by several international regulatory agencies worldwide (Krasner et al., 2001; Roccaro et al. 2014; Singer, 1994; Krasner et al., 2006). Some of these administrations are the United States Environmental Protection Agency (USEPA), World Health Organization (WHO), and the European Union (EC) (Toroz and Uyak, 2005; Uyak, 2006). USEPA and EC have set the maximum contaminant levels (MCL) of 4 THM species (chloroform, bromodichloromethane, dibromochloromethane, and bromoform) as $80 \mu \mathrm{g} \cdot \mathrm{L}^{-1}$ and $100 \mu \mathrm{g} \cdot \mathrm{L}^{-1}$, respectively (Pontius, 1993; Uyak and Toroz, 2006; US EPA, 2003). The limit of THMs is $100 \mu \mathrm{g} \cdot \mathrm{L}^{-1}$ in Turkey.

\footnotetext{
To whom all correspondence should be addressed.

e-mail: omergungor@outlook.com

Received 16 October 2017; accepted in revised form 25 September 2018
}

Prior studies have revealed that THM formation is very complex since it can be affected by several factors including concentration and natural organic matter (NOM) indicators such as specific ultraviolet absorbance (SUVA), total organic carbon (TOC), ultraviolet absorbance at $254 \mathrm{~nm}$ wavelength $\left(\mathrm{UV}_{254}\right)$, water quality parameters (e.g. $\mathrm{pH}$, temperature, inorganic ion (particularly bromide) concentration), and chlorination conditions (e.g., contact time or travel time of water in the system, applied chlorine dose, chlorine residual) (Hasan et al., 2010; Sketchell et al., 1995; Chellam, 2000; Chaib and Moschandreas, 2006; Shmeis et al., 2009; Platikanov et al., 2010). In addition, due to the adverse health effects on humans, several treatment alternatives have been developed to achieve the removal of DBPs like THMs from drinking waters. Coagulation is one of the most common methods used for removing NOM and also DBPs in water (Edzwald and Tobiason, 1999; Kabsch-Korbutowicz, 2005; Hu et al., 2006; Rong et al., 2013). Furthermore, it is more efficient for the removal of the most hydrophobic and high molecular weight fraction of NOM (Roccaro et al., 2014).

Aluminum sulfate (alum) or ferric chloride are known as conventional coagulants that have often been used for removing NOM and DBPs in water sources, for many years. However, DBPs and NOM cannot be effectively removed with conventional coagulation processes alone (Lou et al., 2011; Sharp et al., 2006). In recent years, carbon nanotubes (CNTs) have, in particular, received special attention for their exceptional water treatment capabilities. The high adsorptive potential of CNTs derives from many appealing features of CNTs, such as their well-defined structure and uniform surface, 6 multilayer adsorption characteristics, additional sorption sites, such as the interstitial regions between the CNTs bundles, and the defects on the tubes (Shih and Li, 2008; Fagan et al., 2004). Previous studies have demonstrated that CNTs are effective adsorbents with high adsorption capacities for 
heavy metals (Li et al., 2005; Lu and Chiu, 2006; Wang et al., 2005), phenols (Chen et al., 2008; Lin and Xing, 2008; Yang et al., 2008), and other organic chemicals (Lu et al., 2005; Yang et al., 2006; Yoon et al., 2012). For example, Li et al. (2003) showed that CNTs are good fluoride adsorbents with superior capability to activated carbon. Lu et al. (2005) demonstrated that both $\mathrm{NaClO}$-oxidized single-walled CNTs (SWCNTs) and multiwalled CNTs (MWCNTs) are effective $\mathrm{Zn}^{2+}$ sorbents. Chen et al. (2008) investigated the adsorption of chlorophenols on pristine and functionalized SWCNTs (hydroxylated SWCNTs and carboxylated SWCNTs).

Although many studies have been carried on CNTs and their adsorption properties, few have been conducted on the removal of NOM and chlorinated compounds like THMs from the water environment by using a combination of coagulation with CNTs. Yoon et al. (2012) investigated the removal of NOM from a variety of potential drinking water sources through a combination of coagulation and adsorption with carbon nanomaterials, and the results revealed that combined coagulation-adsorption treatment using carbon nanomaterials can be effective in removing NOM from various water sources. Similarly, Ozdemir (2016) has shown that coagulation processes using carbon nanomaterials can be effective in the removal of THMs from various types of chlorinated source waters.

The prediction of THM levels in drinking water sources under different water quality and treatment conditions is essential in order to exercise quality control and ensure compliance with regulatory guidelines/standards. In the literature, many mathematical models have been proposed for the description of the mechanisms of THM formation and kinetics (Elshorbagy et al., 2000; Abdullah et al., 2003; Sadiq and Rodriquez, 2004; Chowdhury et al., 2009; Ma and Lu, 2012).

Empirical and kinetic THM formation models were quantified as a power function of various quality parameters and obtained by linear and non-linear multi-regression analysis (Sadiq and Rodriguez, 2004; Solarik et al., 2000; Mishra et al., 2016). Furthermore, these models can be used to determine the effect of important parameters, including chlorine dose and residual, contact time, coagulant dose, TOC and $\mathrm{pH}$, on THM formation. For example, Amy et al. (1987) performed a study of 9 different raw water samples throughout the USA, representing a diverse array of characteristics, to obtain a relationship between THM formation and water quality parameters, and developed two types of mathematical models as linear and non-linear. As a result, they determined that the product of dissolved UV absorption (DUV), and nonpurgeable organic carbon (NPOC) was the best surrogate parameter for predicting THM formation.

Thanks to the non-linear statistical model they developed. Lyn and Taylor (1993) found that total trihalomethane (TTHMs) formation was as a function of organic content, reaction time and chlorine dose, after chlorination of raw groundwater from a utility in Florida. Uyak et al. (2007) reported that THM and HAA formations can be described by the multiple linear regression technique. Also, they found that the model regression coefficients of THM and HAA are 0.88 and 0.61, respectively. Gupta and Kumari (2015) developed linear and non-linear predictive models for monitoring THM formation in drinking water supplies. As a result, they determined that the linear model performed better than nonlinear one in terms of percentage prediction errors.

The objective of this study was to develop models using multiple linear regression analysis for the prediction of trihalomethane removal from chlorinated drinking water sources through a combination of a coagulation process with CNTs. Water samples from Terkos Lake, Büyükçekmece Lake and Ulutan Lake, as three important drinking water sources, were used in experiments. SWCNTs and MWCNTs were used as CNTs for determining the removal efficiency of TTHMs in the coagulation process. Moreover, we tried to develop a fitting model applying multiple linear regression analysis for the three coagulated and chlorinated water sources with different water quality characteristics, including conductivity, $\mathrm{pH}, \mathrm{UV}_{254}, \mathrm{TOC}$ and SUVA. This is the first study conducted in Turkey to model THM removal under different chlorination conditions and CNTs. The variables used in this study were TOC concentration, reaction time, chlorine and coagulant doses, SWCNTs and MWCNTs. No previous attempts have been made to develop these models for prediction of TTHMs removal in Turkey. A few studies have focused on the determination of TTHM removal (Hasan et al., 2010; Mishra et al., 2012). In this study, the models were developed against an individual dataset of THM measurements in water samples taken from September 2014 to May 2015 in the same reservoir waters and chlorinated under identical conditions. The models developed for TTHM removal were validated over another period (April 2016). The aim of validation is to measure how well the model fits the experimental data.

\section{MATERIALS AND METHODS}

\section{Source water and sampling}

During this study, water samples were taken from Terkos Lake water (TLW) and Buyukcekmece Lake water (BLW) in Istanbul city and also Ulutan Lake water (ULW) in Zonguldak city, Turkey. The sampling was done in all 4 seasons from 2015 to 2016 (with seasons starting in September 2014, January 2015, May 2015, and April 2016). Approximately 1 million $\mathrm{m}^{3}$ of drinking water per day is provided by the TLW and BLW reservoirs in Istanbul. In addition, ULW is a reservoir that provides nearly $35000 \mathrm{~m}^{3}$ of raw water to the drinkingwater treatment plant of Zonguldak. Raw water samples were collected as a grab sample, shipped to the laboratory on the same day and kept in the dark in a refrigerator at $4^{\circ} \mathrm{C}$ to retard biological activity prior to use.

\section{Coagulation procedure}

Prior to the jar test, stock solutions containing $5000 \mathrm{mg} \cdot \mathrm{L}^{-1}$ of the SWCNTs and MWCNTs were prepared by adding $1 \mathrm{~g}$ of the CNTs to $200 \mathrm{~mL}$ of distilled water and stirring with a magnetic stirrer at $600 \mathrm{r} \cdot \mathrm{min}^{-1}$. The applied coagulant doses ranged from 0 to $100 \mathrm{mg} \cdot \mathrm{L}^{-1}$. Coagulation of TLW, BLW and ULW was carried out by using a Phipps and Bird 6-paddle jar test apparatus. The jars were round beakers with $1 \mathrm{~L}$ capacity. Rapid mixing was at $150 \mathrm{r} \cdot \mathrm{min}^{-1}$ for $2 \mathrm{~min}$; flocculation was carried out at $40 \mathrm{r} \cdot \mathrm{min}^{-1}$ for $30 \mathrm{~min}$. The ferric chloride and alum were consistently used for THM removal at similar dosages, as a coagulant. However, coagulant dose was varied in accordance with the NOM content of the source water, related to hydrophobicity. A dosage of $100 \mathrm{mg} \cdot \mathrm{L}^{-1}$ of alum resulted in the maximum DOC removal for samples from 3 drinking water sources by coagulation. However, based on economic and engineering considerations, $80 \mathrm{mg} \cdot \mathrm{L}^{-1}$ was selected as the optimum coagulant dosage. The optimum combined coagulant dosage for TLW, BLW and ULW was determined as $50 \mathrm{~m} \cdot \mathrm{L}^{-1}$. After the jar tests were completed, the treated water samples were collected and passed through $0.45 \mu \mathrm{m}$-membrane filters for DOC and THM analysis. 


\section{Purified CNTs}

One gram of raw CNTs was dispersed into a $100-\mathrm{mL}$ flask containing $40 \mathrm{~mL}$ of mixed acid solutions $\left(30 \mathrm{ml}\right.$ of $\mathrm{HNO}_{3}$ $+10 \mathrm{~mL}$ of $\mathrm{H}_{2} \mathrm{SO}_{4}$ ) for $24 \mathrm{~h}$ to remove metal catalysts (Ni nanoparticles). After cleaning, the CNTs were again dispersed in a $100-\mathrm{mL}$ flask containing $40 \mathrm{~mL}$ of the mixed acid solutions, which were then shaken in an ultrasonic cleaning bath (Branson 3510 Ultrasonic Cleaner, Connecticut, USA) and heated at $80^{\circ} \mathrm{C}$ in a water bath for $2 \mathrm{~h}$ to remove amorphous carbon. After cooling to room temperature, the mixture was filtered with a $0.45-\mu \mathrm{m}$ glass-fibre filter, and the solid was washed with deionized water until the $\mathrm{pH}$ of the filtrate was 7. The filtered solid was then dried at $80^{\circ} \mathrm{C}$ for $2 \mathrm{~h}$ to obtain the purified CNTs. This procedure for purifying CNTs has been used by other researchers in previous CNT studies (Chungsying et al., 2005). After purifying the CNTs, a simple coagulation process with the application of alum was used for precipitating CNTs from the solution, and CNTs particles were thus recovered. Then, the residual CNT waste was sealed carefully using double layers of polyethylene bags and transported to solid waste incineration plants with other hazardous wastes from the laboratory (HSE, 2009).

\section{Chlorination procedure}

Chlorination of raw water samples was conducted in accordance with Standard Methods 5710 B (APHA, 2005). Before chlorination, sample $\mathrm{pH}$ values were adjusted to 7 by addition of $\mathrm{HCl}$ or $\mathrm{NaOH}$ solution as appropriate. The chlorinated samples were placed into $125 \mathrm{~mL}$ amber glass bottles with polypropylene screw caps and TFE faced septa. The chlorination process was conducted for a given chlorine dosage $\left(10 \mathrm{mg} \cdot \mathrm{L}^{-1}\right)$, fixed $\mathrm{pH}(\mathrm{pH} 7)$, and room temperature $\left(20^{\circ} \mathrm{C}\right)$. Also, the chlorination process was conducted at the chlorine doses of 5 and $10 \mathrm{mg} \cdot \mathrm{L}^{-1}$ and 2, 4 and 168 reaction times for each water sample. After chlorination, the water samples were incubated at $20^{\circ} \mathrm{C}$ for the desired contact time $(168 \mathrm{~h})$. At the end of the reaction period, a quenching agent (sodium sulfite solution) was added to each of the chlorinated water samples for the analysis of THM formation.

\section{Analytical procedure}

All water samples were analysed based on the procedures described in the Standard Methods (APHA, 2005). DOC analysis was conducted by the high-temperature combustion method according to $3510 \mathrm{~B}$ using a Shimadzu- 5000A TOC analyser equipped with an auto-sampler (APHA, 2005). The minimum quantification limit of the analyser was $0.1 \mathrm{mg} \cdot \mathrm{L}^{-1}$ $\mathrm{UV}_{254}$ absorbance readings were carried out by a Shimadzu 1601 UV visible spectrophotometer at a wavelength of 254 nm (APHA, 2005). THM analysis was performed using EPA Method 551.1 (USEPA, 1992) which includes liquid-liquid extraction (LLE) with pentane (Uyak, 2006). For THM, calibration standards were prepared using certified commercial mix solutions (AccuStandard, Inc., purity N99\%). THM analyses were performed with Thermo Scientific TRACE 1300 gas chromatograph. The analysis temperature conditions are $35^{\circ} \mathrm{C}$ for the initial temperature and $4 \mathrm{~min}$ for the hold time. The final temperature is $180^{\circ} \mathrm{C}$ with an increase of $30^{\circ} \mathrm{C} \cdot \mathrm{min}^{-1}$.

\section{A mathematical model for prediction of TTHM removal}

In order to predict TTHM removal in chlorinated water sources, a mathematical model was developed using multilinear regression technique. TTHM removal was designated as the dependent variable, and TOC, SWCNTs dose, MWCNTs, chlorine dose and residence time were defined as independent variables. These independent variables were selected based on the Pearson correlation matrix at 95\% significance level. Both correlation and regression measure the linear relationship between the variables. The goodness of the model fit was evaluated through the examination of various statistical parameters, including regression coefficient $\left(R^{2}\right)$, the $F$ statistic, and $a$ value for linear regression.

\section{RESULTS AND DISCUSSION}

\section{Characterization of NOM precursors in raw waters}

Table 1 presents the average measured organic parameters for 3 surface water supplies. Dissolved organic concentration, $\mathrm{UV}_{254}$ and SUVA are the main surrogate parameters for NOM reactivity in water sources. Although DOC levels are a significant measurement of NOM concentration in water, $\mathrm{UV}_{254}$ is an indicator of the aromatic content of NOM (Trina et al., 1990; Novak et al., 1992). However, most researchers have found that there is strong a correlation between TOC and $\mathrm{UV}_{254}$ levels (Trina et al., 1990; Novak et al., 1992; Mller and Uden, 1983; Stevens et al., 1989).

\begin{tabular}{|l|c|c|c|c|}
\hline \multicolumn{5}{|c|}{ TABLE 1 } \\
\hline \multirow{2}{*}{ Parameters } & \multirow{2}{*}{ Units } & TLW & BLW & ULW \\
\cline { 2 - 5 } & & Average & Average & Average \\
\hline pH & $7.85 \pm 0.12$ & $8.05 \pm 0.16$ & $7.21 \pm 0.13$ \\
\hline Turbidity & $\mathrm{NTU}$ & $4.40 \pm 0.38$ & $5.62 \pm 0.27$ & $3.20 \pm 0.32$ \\
\hline Conductivity & $\mu \mathrm{S} \cdot \mathrm{cm}^{-1}$ & $432 \pm 12.15$ & $513 \pm 14.06$ & $336 \pm 10.5$ \\
\hline Total Hardness & $\mathrm{mgCaCO} \cdot \mathrm{L}^{-1}$ & $126 \pm 5.7$ & $166 \pm 8.47$ & $89 \pm 7.11$ \\
\hline Alkalinity & $\mathrm{mgCaCO} \cdot \mathrm{L}^{-1}$ & $105 \pm 5.4$ & $143 \pm 6.8$ & $73 \pm 4.21$ \\
\hline Temperature & ${ }^{\circ} \mathrm{C}^{-5}$ & $13 \pm 1.2$ & $10 \pm 0.8$ & $14 \pm 1.4$ \\
\hline Br & $\mu \mathrm{g} \cdot \mathrm{L}^{-1}$ & $90 \pm 15$ & $140 \pm 18$ & $60 \pm 11$ \\
\hline TOC & $\mathrm{mg} \cdot \mathrm{L}^{-1}$ & $4.81 \pm 0.51$ & $4.05 \pm 0.39$ & $3.75 \pm 0.2$ \\
\hline UV & $\mathrm{cm}_{254}^{-1}$ & $0.15 \pm 0.01$ & $0.10 \pm 0.008$ & $0.08 \pm 0.007$ \\
\hline SUVA & $\mathrm{L} \cdot \mathrm{mg}^{-1} \cdot \mathrm{m}^{-1}$ & $3.12 \pm 0.12$ & $2.47 \pm 0.14$ & $2.13 \pm 0.11$ \\
\hline THMFP & $\mu \mathrm{g} \cdot \mathrm{L}^{-1}$ & $335 \pm 24$ & $245 \pm 21$ & $195 \pm 17$ \\
\hline
\end{tabular}


The results demonstrated that the highest TOC and $\mathrm{UV}_{254}$ absorbance values were determined in TLW $\left(5.32 \mathrm{mg} \cdot \mathrm{L}^{-1}\right.$ and $\left.0.118 \mathrm{~cm}^{-1}\right)$, followed by BLW $\left(4.52 \mathrm{mg} \cdot \mathrm{L}^{-1}\right.$ and $\left.0.1 \mathrm{~cm}^{-1}\right)$, while ULW had the lowest level of $\mathrm{UV}_{254}$ absorbance value of $0.075 \mathrm{~cm}^{-1}$. Also, SUVA is an effective surrogate parameter and is used for predicting the humic content of NOM and DBP formation in chlorinated water sources (Liang and Singer, 2003). The humic fraction of TLW (SUVA: $3.12 \mathrm{~L} \cdot \mathrm{mg}^{-1} \cdot \mathrm{m}^{-1}$ ) was found to be higher than the other two water sources. Besides, the SUVA values of BLW and ULW were 2.55 and $2.13 \mathrm{~L} \cdot \mathrm{mg}^{-1} \cdot \mathrm{m}^{-1}$, respectively. Uyak et al. (2007) reported that DBP formation rose with increasing SUVA values in surface water supplies. Similarly, the maximum THMFP concentration of $335 \mu \mathrm{g} \cdot \mathrm{L}^{-1}$ was detected in TLW, due to having the highest TOC and $\mathrm{UV}_{254}$ content of water. In addition, the average THMFP values of BLW and ULW were 245 and $195 \mu \mathrm{g} \cdot \mathrm{L}^{-1}$, respectively. This finding also shows that SUVA values are very closely related to quantifying the reactivity of NOM in DBP formation like THMs (Reckhow et al., 1990; Kitis et al., 2002).

\section{Distribution of THMsconcentration in water reservoirs}

During the sample period in this study, THM levels ranged from 195 to $335 \mu \mathrm{g} \cdot \mathrm{L}^{-1}$ for 3 chlorinated water sources within the reaction time of $168 \mathrm{~h}$. As shown in Fig. $1, \mathrm{CHCl}_{3}$ is the predominant THM species during the chlorination of water from TLW, BLW and ULW.

The maximum concentration of $\mathrm{CHCl}_{3}$ was observed as $248.14 \mu \mathrm{g} \cdot \mathrm{L}^{-1}$ in TLW samples, followed by ULW and BLW samples as $141.63 \mu \mathrm{g} \cdot \mathrm{L}^{-1}$ and $110.12 \mu \mathrm{g} \cdot \mathrm{L}^{-1}$, respectively. However, the other THMs, i.e., $\mathrm{CHBr}_{2} \mathrm{Cl}$ and $\mathrm{CHCl}_{2} \mathrm{Br}_{\text {levels }}$ (54.64 and $27.52 \mu \mathrm{g} \cdot \mathrm{L}^{-1}$ ) in TLW and in ULW (32.18 and $19.43 \mu \mathrm{g} \cdot \mathrm{L}^{-1}$ ) were found at levels lower than those of $\mathrm{CHCl}_{3}$.

However, high bromide to organic matter ratios which led to more brominated THMs indicated that bromoform was the major THM species (Amy et al., 1992; Pan and Zhang, 2013). Bromide concentration was highest in BLW at $0.14 \mathrm{mg} \cdot \mathrm{L}^{-1}$, followed by TLW and ULW, in decreasing order, at 0.09 and $0.06 \mathrm{mg} \cdot \mathrm{L}^{-1}$, respectively. Thus, $\mathrm{CHBr}_{2} \mathrm{Cl}$ and $\mathrm{CHCl}_{2} \mathrm{Br}$ concentrations in BLW were higher than that of TLW and ULW. As shown in Fig. 1, bromoform $\left(\mathrm{CHBr}_{3}\right)$ has the lowest concentration of the trihalomethane species in all water samples. Although the maximum $\mathrm{CHBr}_{3}$ concentration was measured to be $13.34 \mu \mathrm{g} \cdot \mathrm{L}^{-1}$ in chlorinated BLW within the reaction time of $168 \mathrm{~h}$, TLW and ULW showed concentrations ranging from 5 to $2 \mu \mathrm{g} \cdot \mathrm{L}^{-1}$. These results have also been reported by several other studies (Kampioti, 2002; Hu et al., 2009; Yang et al., 2005). In our study, these outcomes have also demonstrated that chlorinated THMs predominated over brominated THMs in water sources. This is consistent with the results obtained by Ates et al. (2007) and Golfinopoulos and Nikolaou (2005).

\section{Effect of coagulation process on THM removal}

In this study, the coagulation process of chlorinated raw water samples was conducted by conventional coagulant (alum) and increasing doses of SWCNTs and MWCNTs, with the addition of alum for 3 chlorinated water sources in the jar-testing procedure. As shown in Fig. 2, the greatest percentage TTHM removal was observed in TLW with combined coagulation by alum in chlorinated TLW (\%94), followed by BLW (\%80) and ULW (\%76), within the reaction time of $168 \mathrm{~h}$.

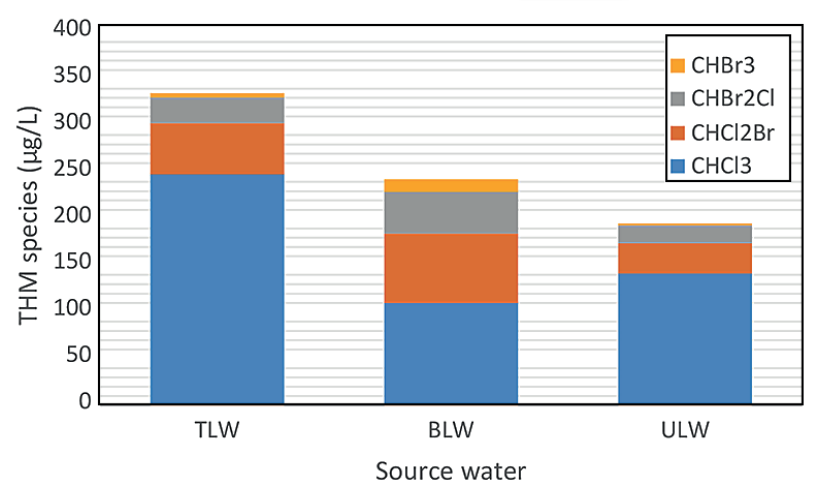

Figure 1

Formation of THM species in three chlorinated water sources

This result demonstrated that, due to the coagulation process, the hydrophobic portion of NOM is removed more than the hydrophilic portion. Thus, the highest TTHM removal was determined in TLW samples with SUVA $=3.12 \mathrm{~L} \cdot \mathrm{mg}^{-1} \cdot \mathrm{m}^{-1}$. The highest TTHM removal using only SWCNTs was recorded in TLW (73.52\%), followed by BLW (68.5\%) and ULW (62.25\%) Similar to SWCNTs, the highest percentage of TTHM removal using only MWCNTs was obtained at about $67 \%$ in TLW. Also, although the removal percentage of TTHM was slightly lower in TLW when using only MWCNTs (67.52\%) than when using SWCNTs (73.52\%), high levels of TTHM removal were observed using only MWCNTs, with $74.23 \%$ and $70.42 \%$ for BLW and ULW, respectively.

As can be seen in Fig. 2, the removal percentage for TTHM was significantly higher in BLW $(87.23 \%)$ and ULW (84.14\%) when using MWCNTs + alum than when using SWCNTs + alum, at $80.63 \%$ and $76.22 \%$, respectively. Among the chlorinated water sources, the maximum TTHM removal was observed in TLW (94.21\%) with SWCNTs + alum. Also, TTHM removal ratio was slightly lower in TLW when using MWCNTs + alum (82.48\%). This outcome revealed that the hydrophilic NOM detected in BLW $\left(\mathrm{SUVA}=2.47 \mathrm{~L} \cdot \mathrm{mg}^{-1} \cdot \mathrm{m}^{-1}\right)$ and ULW (SUVA $=2.13 \mathrm{~L} \cdot \mathrm{mg}^{-1} \cdot \mathrm{m}^{-1}$ ) was more easily removed by MWCNTs than by SWCNTs.

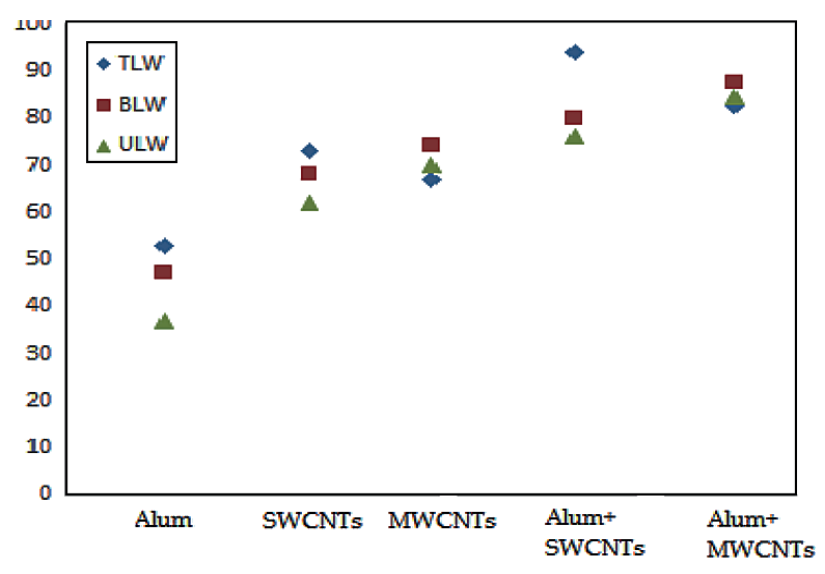

Figure 2

Comparison of TTHMs removal using conventional coagulation (only alum) and combined coagulation processes. Optimum alum dose $=$ $80 \mathrm{mg} \cdot \mathrm{L}^{-1}$ and combined coagulant dose $=50 \mathrm{mg} \cdot \mathrm{L}^{-1}$. 
Moreover, chlorinated TLW, BLW and ULW samples were coagulated by the increasing doses of alum. The maximum TTHM removal when using only alum was recorded in TLW (53\%), followed by BLW (42\%) and ULW (37\%) (Fig. 2). For 3 chlorinated water sources, TTHM removal was low when using only alum, while high TTHM removals were determined with combined coagulation. Furthermore, the combined coagulation using CNTs was more efficient than the conventional coagulant in the removal of TTHM from chlorinated TLW, BLW and ULW. Prior studies have also reported this finding (Lu and Chiu, 2006; Wang et al., 2005; Wei and Yue, 2009; Zhao et al., 2013).

\section{Effects of chlorine dosage and contact time on TTHM formation}

In this study, raw and coagulated water samples were chlorinated to provide data on THM formation in 2, 24 and 168 $\mathrm{h}$ reaction time with 2 different chlorine doses, at $\mathrm{Cl}_{2}=10$ and $5 \mathrm{mg} \cdot \mathrm{L}^{-1}$. According to Table 2, the maximum THM formation was observed when the highest chlorine dose $\left(\mathrm{Cl}_{2}=10 \mathrm{mg} \cdot \mathrm{L}^{-1}\right)$ was applied to each raw water sample prior to coagulation within the reaction time of $168 \mathrm{~h}$.

As shown in Table 2, TTHM concentrations of TLW, BLW and ULW were 256.12, 198.77 and $176.04 \mu \mathrm{g} \cdot \mathrm{L}^{-1}$, respectively, at the reaction time of $168 \mathrm{~h}$ and the chlorine dosage of $10 \mathrm{mg} \cdot \mathrm{L}^{-1}$. On the contrary, for chlorine dosage at $5 \mathrm{mg} \cdot \mathrm{L}^{-1}$, the amounts of TTHMs formed were measured to be 183.26, 123.51 and 102.69 $\mu \mathrm{g} \cdot \mathrm{L}^{-1}$ for TLW, BLW and ULW samples at the reaction time of $168 \mathrm{~h}$, respectively. Concurring with the literature, these outcomes implied that the amount of THM increased with increasing chlorine dosage and reaction time. (Rodriguez and Serodes, 2001; Toroz and Uyak, 2005).

\section{Effects of THM precursors on THM removal}

TOC, $\mathrm{UV}_{254}$ and SUVA are the most important surrogate parameters used to predict NOM reactivity and DBP formation. Among these parameters, TOC is an indicator measurement for the NOM and DBP levels in water. In other words, the change in TOC concentration is related to the production of DBPs like THMs in chlorinated water sources. A higher TOC level is, thus, likely to produce more THMs. As shown in Table 1, the highest TOC concentration $\left(4.81 \mathrm{mg} \cdot \mathrm{L}^{-1}\right)$ was observed at the highest THMF concentration $\left(335 \mu \mathrm{g} \cdot \mathrm{L}^{-1}\right)$ in chlorinated TLW. Similarly, among the chlorinated water samples, the largest percentage of maximum TTHM removal (94\%) using SWCNTs + alum was observed at the highest TOC concentration, in TLW within the reaction time of 168 hours. Besides, higher TTHM removals in chlorinated BLW (87\%) and ULW (84\%) using MWCNTs + alum were recorded to be
4.05 and $3.75 \mathrm{mg} \cdot \mathrm{L}^{-1}$ as TOC concentrations. In addition, $\mathrm{UV}_{254}$ is a reasonable surrogate for TOC concentrations, not only in natural waters (Brandstetter et al., 1996) but also in other environments such as sediment pore waters (Deflandre and Gagne, 2001). As can be seen in Fig. 3, among the chlorinated water samples, the largest percentage of maximum TTHM removal using SWCNTs and alum was observed in TLW with

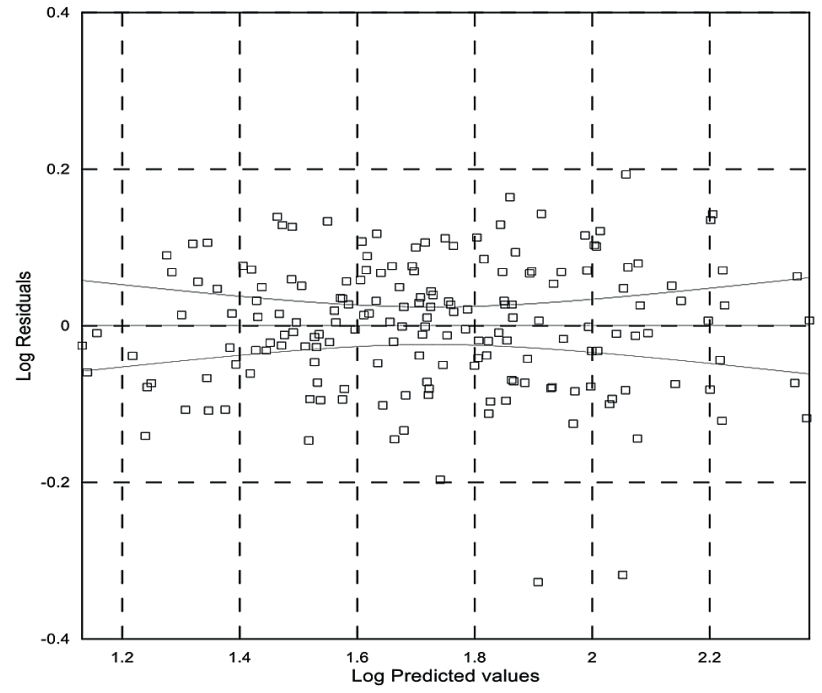

(a)

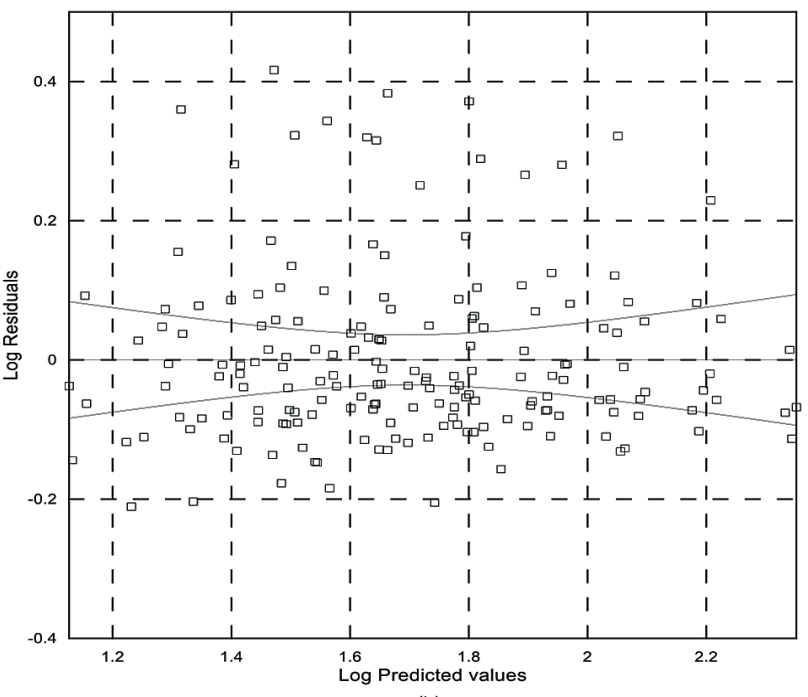

(b)

Figure 3

Plot of residuals versus predicted THM values for (a) Model 1 and (b) Model 2

TABLE 2

Formation of TTHMs in chlorinated TLW, BLW and ULW samples for varying reaction times and chlorine dosages

\begin{tabular}{|l|c|c|c|c|c|c|}
\hline Source waters & \multicolumn{2}{|c|}{ TLW } & \multicolumn{2}{c|}{ BLW } & \multicolumn{2}{c|}{ ULW } \\
\hline \multirow{2}{*}{ Reaction times (h) } & TTHM $\left(\boldsymbol{\mu g} \cdot \mathrm{L}^{-1}\right)$ & TTHM $\left(\boldsymbol{\mu g} \cdot \mathrm{L}^{-1}\right)$ & TTHM $\left(\boldsymbol{\mu g} \cdot \mathrm{L}^{-1}\right)$ & TTHM $\left(\boldsymbol{\mu g} \cdot \mathrm{L}^{-1}\right)$ & TTHM $\left(\boldsymbol{\mu g} \cdot \mathrm{L}^{-1}\right)$ & TTHM $\left(\boldsymbol{\mu g} \cdot \mathrm{L}^{-1}\right)$ \\
\cline { 2 - 7 } & $\mathrm{Cl}_{2}=\mathbf{1 0}\left(\mathbf{m g} \cdot \mathrm{L}^{-1}\right)$ & $\mathrm{Cl}_{2}=\mathbf{5}\left(\mathbf{m g} \cdot \mathrm{L}^{-1}\right)$ & $\mathrm{Cl}_{2}=\mathbf{1 0}\left(\mathbf{m g} \cdot \mathrm{L}^{-1}\right)$ & $\mathrm{Cl}_{2}=\mathbf{5}\left(\mathbf{m g} \cdot \mathrm{L}^{-1}\right)$ & $\mathrm{Cl}_{2}=\mathbf{1 0}\left(\mathbf{m g} \cdot \mathrm{L}^{-1}\right)$ & $\mathrm{Cl}_{2}=\mathbf{5}\left(\mathbf{m g} \cdot \mathrm{L}^{-1}\right)$ \\
\hline 2 & 68.22 & 54.68 & 61.02 & 42.24 & 51.49 & 37.88 \\
\hline 24 & 193.34 & 121.06 & 135.58 & 67.26 & 113.14 & 56.33 \\
\hline 168 & 256.12 & 183.26 & 198.77 & 123.51 & 176.04 & 102.69 \\
\hline
\end{tabular}


the highest $\mathrm{UV}_{254}$ value at $0.15 \mathrm{~cm}^{-1}$ followed by BLW and ULW using MWCNT + alum at 0.1 and $0.08 \mathrm{~cm}^{-1}$, respectively. Among these parameters, SUVA has significant potential effects on the humic content of NOM and formation of chlorination by-products. For the three water samples studied, the highest TTHM removal by combined SWCNT and alum coagulation, at about 95\%, was determined in chlorinated TLW samples with a SUVA value of $3.12 \mathrm{~L} \cdot \mathrm{mg}^{-1} \cdot \mathrm{m}^{-1}$. On the contrary, the lowest TTHM removal using only alum coagulation was observed in ULW samples with SUVA value of $2.13 \mathrm{~L} \cdot \mathrm{mg}^{-1} \cdot \mathrm{m}^{-1}$. Similar to the studies in the literature, this result shows that the hydrophilic portion of NOM with lower SUVA values was not effective for TTHM removal with conventional coagulation process. (Özdemir, 2014; Özdemir et al., 2013; Worrall and Burt 2009).

\section{Modelling the TTHM removal by CNTs}

The development of multiple regression models for predicting TTHM removal for chlorinated water from TLW, BLW, and ULW was based on the use of TOC values, chlorine contact time, chlorine dose and the doses of SWCNTs and MWCNTs. The multilinear regression models obtained for this study are as follows:

$$
T H M=10^{3.756} \times S W C N T^{-1.232} \times \text { TOC }^{-1.172} \times C l_{2}^{0.479} \times \text { Time }^{0.174}
$$

$$
T H M=10^{3.363} \times M W C N T^{-1.041} \times \mathrm{TOC}^{-0.931} \times \mathrm{Cl}_{2}^{0.520} \times \mathrm{Time}^{0.150}
$$

Table 3 and Table 4 illustrate the outcomes of Pearson matrix correlations for the examination of the relationships between the variables.

A moderate relationship $(r=0.702)$ was obtained between the amount of TTHM and chlorine dose for Model 1. Moreover, for Model 2, Pearson regression tests also showed a moderate correlation $(r=0.641)$ between the amount of TTHM and chlorine dose. Similarly, for Model 1, a medium level of correlation $(r=0.642)$ was determined between the amount of TTHM and TOC values, followed by that for Model $2(r=$ 0.655). Prior research suggested that strong correlations were obtained between TOC and amount of TTHM due to the coagulation process (Toroz and Uyak, 2005; Uyak, 2006; Pontius, 1993; Uyak and Toroz, 2006). However, an inverse relationship $(r=-0.689)$ between the amount of TTHM and SWCNT dosage was observed for Model 1. As discussed in the earlier studies in the literature, a similar relationship was obtained between the amount of TTHM and MWCNT dosage $(r=-0.697)$ for Model 2 . (Liang and Singer, 2003; Nikolaou et al., 2004).

Table 5 and Table 6 present the ANOVA results for the regression coefficients, the standard errors and the $t$-values for the variables included in the developed models. Statistical examination showed that the residuals of the models follow a normal distribution (Draper and Smith, 1981) and the mean value of the residuals should be zero. Beta is the referred regression coefficient for each independent variable.

As can be seen in Fig. 3, the mean value of residuals is zero, and they are evenly distributed above and below the zero baselines for Models 1 and 2. Since the $R^{2}$ value of Model 1 is higher than that of Model 2, the residuals and predicted values of Model 1 are closer to the zero line than that of Model 2 (Fig. 3).

Figure 4 shows the comparison between predicted and observed values for Model 1. Model 1 gives a satisfactory fit, in
TABLE 3

Pearson correlation coefficients of THM for SWCNTs

\begin{tabular}{|l|c|c|c|c|c|}
\hline & $\begin{array}{c}\text { Log } \\
\text { THM }\end{array}$ & $\begin{array}{c}\log \text { Alum } \\
\text { dosage }\end{array}$ & $\log \mathrm{TOC}$ & $\log \mathrm{Cl}_{2}$ & $\begin{array}{c}\text { log } \\
\text { Time }\end{array}$ \\
\hline $\log \mathrm{THM}$ & 1.000 & & & & \\
\hline $\log \mathrm{SWNT}$ & -0.689 & 1.000 & & & \\
\hline $\log \mathrm{TOC}$ & 0.642 & -0.966 & 1.000 & & \\
\hline $\log \mathrm{Cl}_{2}$ & 0.702 & -0.477 & 0.503 & 1.000 & \\
\hline $\log$ Time & 0.502 & -0.005 & 0.004 & 0.033 & 1.000 \\
\hline
\end{tabular}

\begin{tabular}{|l|c|c|c|c|c|}
\hline \multicolumn{7}{|c|}{ TABLE 4 } \\
\hline & Pearson correlation coefficients of THM for MWCNTs \\
\hline & $\begin{array}{c}\text { log Alum } \\
\text { dosage }\end{array}$ & $\log$ TOC & $\log \mathrm{Cl}_{2}$ & $\begin{array}{c}\text { log } \\
\text { Time }\end{array}$ \\
\hline $\log \mathrm{THM}$ & 1.000 & & & & \\
\hline $\begin{array}{l}\log \\
\mathrm{MWNT} \\
30-50 \mathrm{~nm}\end{array}$ & -0.697 & 1.000 & & & \\
\hline $\log \mathrm{TOC}$ & 0.655 & -0.971 & 1.000 & & \\
\hline $\log \mathrm{Cl}_{2}$ & 0.673 & -0.431 & 0.443 & 1.000 & \\
\hline $\log \mathrm{Time}$ & 0.400 & 0.000 & -0.030 & -0.013 & 1.000 \\
\hline
\end{tabular}

\begin{tabular}{|c|c|c|c|c|}
\hline \multicolumn{5}{|c|}{$\begin{array}{c}\text { TABLE } 6 \\
\text { Regression analysis coefficients for MWNT 30-50nm of THM } \\
\text { model }\end{array}$} \\
\hline THM & B & Standard error & $t$-values & $p$-level \\
\hline Constant & 3.363 & 0.420 & 8.016 & $<0.001$ \\
\hline $\begin{array}{l}\log M W N T \\
30-50 \mathrm{~nm}\end{array}$ & -1.041 & 0.161 & -6.462 & $<0.001$ \\
\hline $\log \mathrm{TOC}$ & -0.931 & 0.330 & -2.824 & 0.005 \\
\hline $\log \mathrm{Cl}_{2}$ & 0.520 & 0.038 & 13.653 & $<0.001$ \\
\hline logTime & 0.150 & 0.012 & 12.511 & $<0.001$ \\
\hline
\end{tabular}

\begin{tabular}{|l|c|c|c|c|}
\hline \multicolumn{5}{|c|}{ TABLE 5 } \\
Regression analysis coefficients for SWNT of THM model \\
\hline THM & B & Standard error & $\boldsymbol{t}$-values & $\boldsymbol{p}$-level \\
\hline constant & 3.756 & 0.219 & 17.186 & $<0.001$ \\
\hline $\operatorname{logSWNT}$ & -1.232 & 0.097 & -12.702 & $<0.001$ \\
\hline $\operatorname{logTOC}$ & -1.172 & 0.156 & -7.522 & $<0.001$ \\
\hline $\operatorname{logCl}$ & 0.479 & 0.024 & 19.645 & $<0.001$ \\
\hline $\operatorname{logTime}$ & 0.174 & 0.008 & 22.017 & $<0.001$ \\
\hline
\end{tabular}

agreement with the results of previous studies (Golfinopoulos, 1998; Uyak et al., 2005; Nikolaoua et al., 2004). Although Model 2 gives good results with a moderate $R^{2}$ value, it may be necessary to more precisely predict TTHM removal (Fig. 4). The use of different coagulants in the coagulation process and TOC concentrations for TTHM could be the reason for this result. Figure 4 indicates that for TTHM removal, Model $1 \mathrm{can}$ estimate more precisely than Model 2.

As shown in Table 7, although these two models are statistically significant, Model 1 gives slightly better prediction performances compared to Model 2. For example, RMSE 


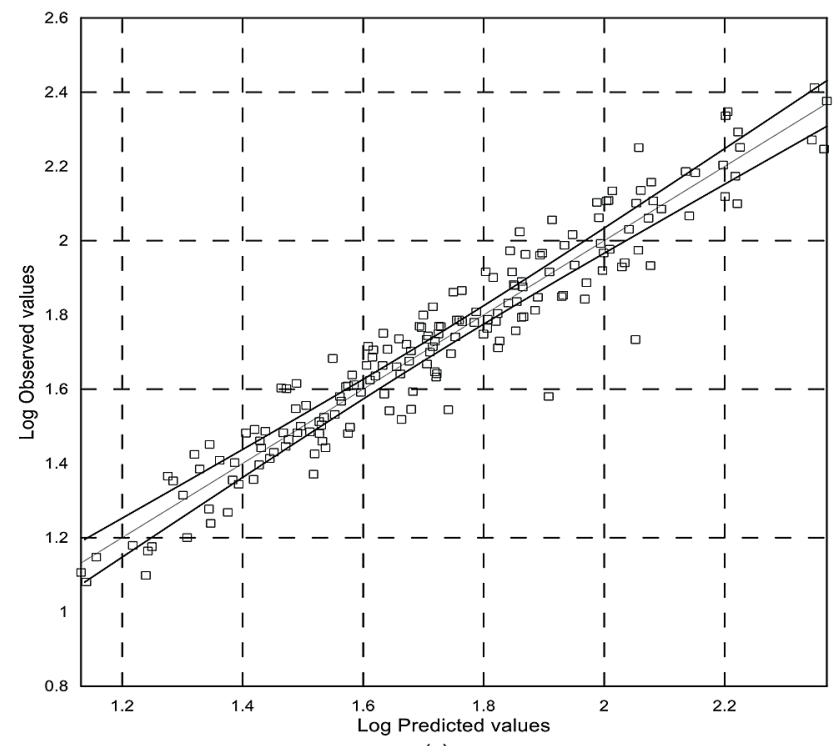

(a)

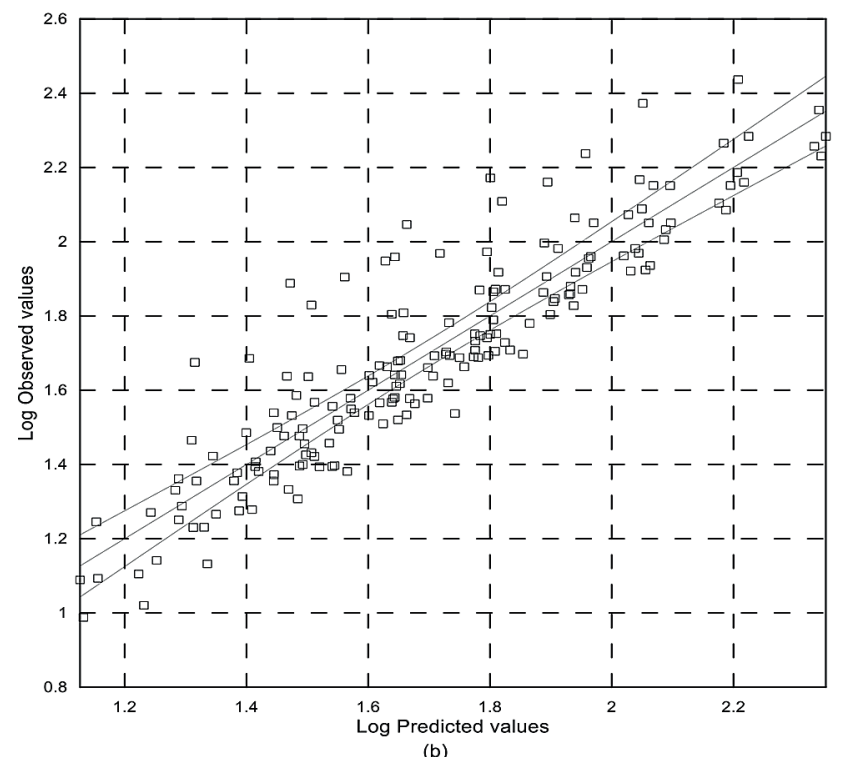

(b)

Figure 4

Comparison between predicted and observed THM values of (a) Model 1 and (b) Model 2

\begin{tabular}{|l|c|c|c|c|c|}
\hline \multicolumn{7}{|c|}{ TABLE 7 } \\
\hline Model & $\boldsymbol{R}$ & $\boldsymbol{R}^{\mathbf{2}}$ & $\begin{array}{c}\text { Adjusted } \\
\boldsymbol{R}^{\mathbf{2}}\end{array}$ & F value & RMSE \\
\hline Model 1 & 0.957 & 0.916 & 0.915 & 477.1 & 0.083 \\
\hline Model 2 & 0.910 & 0.829 & 0.825 & 211.9 & 0.126 \\
\hline
\end{tabular}

values were 0.083 and 0.126 for Model 1 and Model 2, respectively. This also shows that Model 1 more precisely predicts TTHM removal compared to Model 2.

The models developed for TTHM removal were validated against an individual dataset of THM measurements in water samples taken during another period (April 2016) from the same reservoir water sources and chlorinated under identical conditions of this study. The aim of validation is to measure how well the model fits the experimental data. Figure 5 shows the results of observed and predicted TTHM removal values for Model 1 and Model 2, respectively. In order to validate these models, the TTHM removal was predicted using Model 1 and Model 2 for an independent set of data and compared with the experimental data.

The Model 1 validation indicates very satisfactory predictions with an $R^{2}$ value of 0.88 , while validation of Model 2 shows a relatively good estimation with an $R^{2}$ value of 0.77 . The validation results are at a satisfactory level for explanation of the observed variability for 3 water sources. Moreover, the results demonstrate that under these experimental conditions, indicating the variations of chlorine dosage, chlorine contact time, TOC concentration and SWCNT and MWCNT dosage, TTHM removal can be well described by multilinear regression technique. These findings are consistent with the results obtained by similar previous studies (Babei et al., 2015; Feungpean et al., 2015).

In this study, with the use of these two models, it is possible to estimate TTHM removal ratios in chlorinated raw water of 3 surface water supplies. However, TTHM removal values can be estimated more accurately with Model 1 for 3 chlorinated
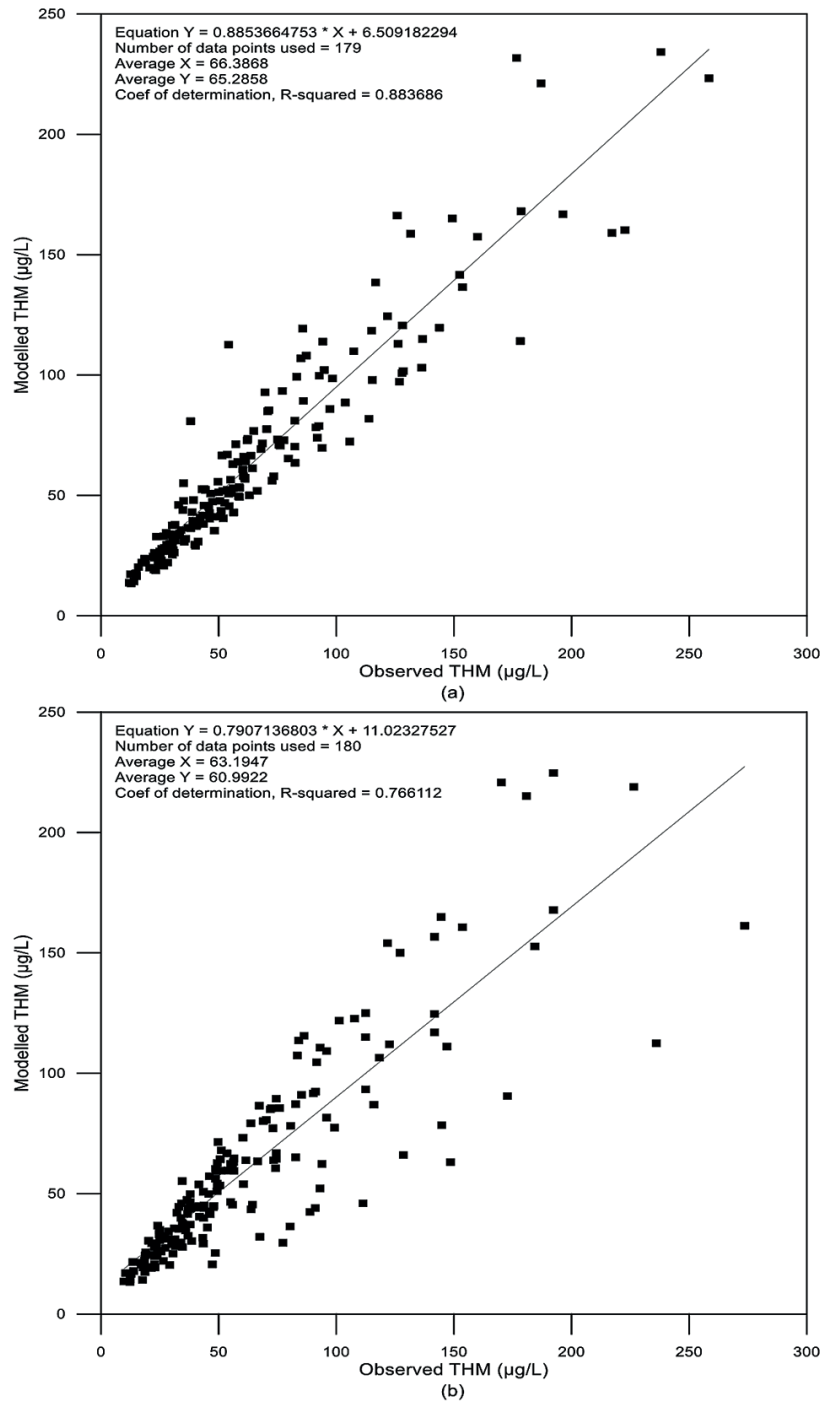

Figure 5

Validation of the model for predicted and measured THM values of (a) Model 1 and (b) Model 2 
water sources. In the past, several studies have proposed many complex statistical models for DBP formation (Golfinopoulos and Arhonditsis, 2002; Chowdhury and Champagne, 2008). However, these models were restricted to field data within the ranges of specific datasets and low inaccurate predictions of THM concentrations.

\section{CONCLUSIONS}

In this study, the maximum THMFP concentration was observed in the chlorinated TLW samples, atan average of 335 $\mu \mathrm{g} \cdot \mathrm{L}^{-1}$, along with the highest SUVA value $\left(3.12 \mathrm{~L} \cdot \mathrm{mg}^{-1} \cdot \mathrm{m}^{-1}\right.$ ). The major THM species formed during the chlorination of water from TLW and ULW was $\mathrm{CHCl}_{3}$ followed by $\mathrm{CHCl}_{2} \mathrm{Br}$ and $\mathrm{CHBr}_{2} \mathrm{Cl}$, respectively. Since $\mathrm{BLW}$ had the highest bromide concentration, $\mathrm{CHBr}_{2} \mathrm{Cl}$ and $\mathrm{CHCl}_{2} \mathrm{Br}$ concentrations in BLW were higher than that of TLW and ULW. Among the THM species, $\mathrm{CHBr}_{3}$ had the lowest concentration, ranging from 5.99 to $0.45 \mu \mathrm{g} \cdot \mathrm{L}^{-1}$ for 3 water sources. During the experimental conditions, the coagulation processes were conducted by alum and by adding alum to CNTs according to the jar-test procedure. The maximum TTHM removal was observed with SWCNTs + alum in the chlorinated samples (94\%) within the reaction time of $168 \mathrm{~h}$.

In addition, the hydrophilic NOM detected in BLW (SUVA $\left.=2.47 \mathrm{~L} \cdot \mathrm{mg}^{-1} \cdot \mathrm{m}^{-1}\right)$ and ULW $\left(\mathrm{SUVA}=2.13 \mathrm{~L} \cdot \mathrm{mg}^{-1} \cdot \mathrm{m}^{-1}\right)$ was more easily removed by MWCNTs than by SWCNTs. For example, TTHM removals using MWCNTs + alum in BLW and ULW were $87 \%$ and $84 \%$, whereas this removal was recorded as $82 \%$ in TLW. This result revealed that the hydrophilic portion of NOM was more easily removed by MWCNTs than by SWCNTs. Furthermore, the results of the coagulation processes show that combined coagulation is very efficient in TTHM removal from chlorinated TLW, BLW and ULW samples. In this paper, parameters affecting TTHM removal were investigated initially using surrogate parameters; TOC, $\mathrm{UV}_{254}$ and SUVA. The experimental results showed that the highest TTHM removal was obtained in chlorinated TLW with the highest TOC (4.81 $\left.\mathrm{mg} \cdot \mathrm{L}^{-1}\right)$ and $\mathrm{UV}_{254}\left(0.15 \mathrm{~cm}^{-1}\right)$ values. Furthermore, the highest TTHM removal was observed at high concentrations of hydrophobic fractions of NOM. Also, the influence of the humic character of the water affects the reactivity of water with chlorine. In other words, higher SUVA values have more phenolic and carboxylic groups which prompt THM removal. Therefore, as presented in the literature, TLW has the maximum THM removal of $94 \%$ because of its high SUVA content, followed by BLW and ULW, recorded as $87 \%$ and $84 \%$, respectively (Özdemir, 2016; Uyak et al., 2007; Özdemir et al., 2013; Uyak et al., 2005; Zhang et al., 2011).

In this study, two models, Model 1 and 2, were developed for predicting TTHM removal by multilinear regression approaches using combined coagulation process in TLW, BLW and ULW under the given chlorination conditions. By using the two models, it is possible to predict the TTHM in Istanbul and Zonguldak reservoir waters. This modelling effort can be very useful for developing general methodological tools that predict the amount of THM based on raw water characteristics and disinfection practices, and can assist the utility operators to conform to the legislative measures. Models 1 and 2 were obtained as a linear equation using several variables: TOC concentration, chlorine dosage, residual time and SWCNT and MWCNT dosages. By using either of the two models, it is possible to predict THM removal in three drinking water sources. In order to evaluate the performance of the two models, the number of observations, $N, F, R^{2}$, standard error of estimate and RMSE were used as statistical variables, respectively. According to the variables, the better results were determined by Model 1 for RMSE and $R^{2}$ values as 0.083 and 0.88 , respectively. They also perform at a satisfactory level for the explanation of the observed variability for three water resources. The slightly lower $R^{2}$ value for Model 2 compared to that for Model 1 shows that Model 1 is more precise for the prediction of THM removal. In other words, the validations of the two models as Model 1 and Model 2 demonstrate satisfactory predictions with $R^{2}$ values of 0.88 and 077 , respectively.

One of the most significant results of this study is that THM removal can be simply predicted using Models 1 and 2 without using the other sophisticated models for only three water sources. In addition, it appeared that under these experimental conditions, THM removal in water does not have a more stochastic character, which is easily described by the multiple regression method. Future study in this area must be directed toward the study of spatial and temporal variation in DBP levels in different water sources.

\section{ACKNOWLEDGEMENTS}

The authors are indebted to the research fund of the Scientific and Technological Research Council of Turkey for supporting this study under Project Number 114Y030. This paper has been proofread by Fatma TANRIVERDİ-KÖKSAL, a member of the Bulent Ecevit University, Article Proofreading and Editing Office.

\section{REFERENCES}

ABDULLAH MA, YEW CH and RAMLI MS (2003) Formation, modeling and validation of trihalomethanes (THM) in Malaysian drinking water: a case study in the districts of Tampin, Negeri Sembilan and Sabak Bernam, Selangor, Malaysia. Water Res. 37 4637-4644. https://doi.org/10.1016/j.watres.2003.07.005

AMY GL, CHADIK PA and CHOWDURY ZK (1987) Developing models for predicting trihalomethane formation potential kinetics. J Am. Water Works Assoc. 79 (7) 89. https://doi.org/ 10.1002/j.15518833.1987.tb02878.x

AMY GL, TAN L and DAVIS MK (1991) The effects of ozonation and activated carbon adsorption on trihalomethane speciation. Water Res. 25 (2) 191-202. https://doi.org/10.1016/0043-1354(91)90029-P

APHA (2005) Standard Methods for the Examination of Water and Waste Water (21 st edn). APHA, Washington, DC.

ARORA H, LECHEVALLIER MW and DIXON KL (1997) DBP Occurrence Survey. J. Am. Water Works Assoc. 89 (6) 60. https:// doi.org/10.1002/j.1551-8833.1997.tb08242.x

ATES N, KITIS M and YETIS U (2007) Formation of chlorination by-products in waters with low SUVA-correlations with SUVA and differential UV spectroscopy. Water Res. 41 4139-4148. https:// doi.org/10.1016/j.watres.2007.05.042

BABAEI AA, ATARI L, AHMADI M, AHMADIANGALI K, ZAMANZADEH M and ALAVI N (2015) Trihalomethanes formation in Iranian water supply systems: predicting and modeling. J. Water Health. 13 (3) 859-869. https://doi.org/10.2166/ wh. 2015.211

BELLAR TA, LICHTENBERG JJ and KRONER RC (1974) The occurrence of organohalides in chlorinated drinking waters. J. Am. Water Works Assoc. 66 703-706. https://doi. org/10.1002/j.1551-8833.1974.tb02129.x

BRANDSTETTER A, SLETTEN RS, MENTLER A and WENZEL WW (1996) Estimating dissolved organic carbon in natural waters by UV absorbance(254 nm). Z. Pflanz. Bodenkunde 159 605-617. https://doi.org/10.1002/jpln.1996.3581590612

CHAIB E and MOSCHANDREAS D (2006) Modeling spatial variation of brominates trihalomethane in a water distribution system of 
Ontario, Canada. J. Environ. Sci. Health A 41 (11) 2447-2464. https://doi.org/10.1080/10934520600927336

CHELLAM S (2000) Effects of nanofiltration on trihalomethane and haloacetic acid precursors removal and speciation in waters containing low concentrations of bromide ion. Environ. Sci. Technol. 34 (9) 1813-1820. https://doi.org/10.1021/es991153t

CHEN W, DUAN L, WANG LL and ZHU DQ (2008) Adsorption of hydroxyl- and amino-substituted aromatics to carbon nanotubes. Environ. Sci. Technol. 42 6862-6868. https://doi.org/10.1021/ es8013612

CHOWDHURY S and CHAMPAGNE P (2008) An investigation on parameters for modeling THMs formation. Global NEST J. 1 80-91. https://doi.org/10.30955/gnj.000518

CHOWDHURY S, CHAMPAGNE P and MCLELLAN PJ (2009) Models for predicting disinfection byproduct (DBP) formation in drinking waters: a chronological review. Sci. Total Environ. $\mathbf{4 0 7}$ 4189-4206. https://doi.org/10.1016/j.scitotenv.2009.04.006

CHUNGSYING L, CHUNG YL and CHANG KF (2005) Adsorption of trihalomethanes from water with carbon nanotubes. Water Res. 39 1183-1189. https://doi.org/10.1016/j.watres.2004.12.033

DEFLANDRE B and GAGNE JP (2001) Estimation of dissolved organic carbon(DOC) concentrations in nanoliter samples using UV spectroscopy. Water Res. 35 3057-3062. https://doi.org/10.1016/ S0043-1354(01)00024-0

DRAPER N and SMITH H (1981) Applied Regression Analysis. John Wiley and Sons, New York.

EDZWALD JK and TOBIASON JE (1999) Enhanced coagulation: US requirements and a broader view. Water Sci. Technol. 40 (9) 63-70. https://doi.org/10.1016/S0273-1223(99)00641-1

ELSHORBAGY WE, ABU-QADAIS H and ELSHEAMY MK (2000) Simulation of THM species in water distribution systems. Water Res. 34 3431-3349. https://doi.org/10.1016/S0043-1354(00)00231-1

FAGAN SB, SOUZA AG, LIMA JO, MENDES GJ, FERREIRA OP, MAZALI IO, ALVES OL and DRESSELHAUS MS (2004) 1,2-Dichlorobenzene interacting with carbon nanotubes. Nano Lett. 4 1285-1288. https://doi.org/10.1021/n10493895

FEUNGPEAN M, PANYAPINYOPOL B, ELEFSINIOTIS P and FONGSATITKUL P (2015) Development of statistical models for trihalomethane (THM) occurrence in a water distribution network in Central Thailand. Urban Water J. 12 (4) 275-282. https://doi.org/ 10.1080/1573062X.2013.871042

GOLFINOPOULOS SK, XILOURGIDIS K, KOSTOPOULOU N and LEKKAS TD (1998) Use of a multiple regression model for predicting trihalomethane formation. Water Res. 32 (9) 2821-2829. https://doi.org/10.1016/S0043-1354(98)00022-0

GOLFINOPOULOS SK and ARHONDITSIS GB (2002) Multiple regression models: a methodology for evaluating trihalomethane concentrations in drinking water from raw water characteristics. Chemosphere 47 1007-1018. https://doi.org/10.1016/ S0045-6535(02)00058-9

GOLFINOPOULOS SK and NIKOLAOU AD (2005) Survey of disinfection by-products in drinking water in Athens, Greece. Desalination 176 (1-3) 13-24. https://doi.org/10.1016/j. desal.2004.10.029

GUPTA SK and KUMARI M (2015) Modeling of trihalomethanes (THMs) in drinking water supplies: a case study of eastern part of India. Environ. Sci. Pollut. Res. 22 12615-12623. https://doi. org/10.1007/s11356-015-4553-0

HASAN A, THACKER NP and BASSIN J (2010) Trihalomethane formation potential in treated water supplies in urban metro city. Environ. Monit. Assess. 168 (1-4) 489-497. https://doi.org/10.1007/ s10661-009-1129-9

HSE (2009) Health and Safety Executive, Risk management of carbon nanotubes.

HU CZ, LIU HJ and QU HH (2006) Coagulation behavior of aluminum salts in eutrophic water: significance of Al-13 species and pH control. Environ. Sci. Technol. 40 325-331. https://doi. org/10.1021/es051423+

HU S, YANG F, LIU S and YU L (2009) The development of a novel hybrid aerating membrane-anaerobic baffled reactor for the simultaneous nitrogen and organic carbon removal from wastewater. Water Res. 43 381. https://doi.org/10.1016/j. watres.2008.10.041
KAMPIOTI A (2002) The impact of bromide on the formation of neutral and acidic disinfection by-products (DBPs) in Mediterranean chlorinated drinking water. Water Res. 36 (10) 2596-2606. https://doi.org/10.1016/S0043-1354(01)00470-5

KITIS M, KARANFIL T and WIGTON A (2002) Probing reactivity of dissolved organic matter for disinfection byproduct formation using XAD-8 resin adsorption and ultrafiltration fractionation. Water Res. 36 (15) 3834-3848. https://doi.org/10.1016/ S0043-1354(02)00094-5

KRASNER SW, MCGUIRE MJ, JACANGELO JG, PATANIA NL, REGAN KM and MARCO AE (2001) Occurrence of disinfection by-products in US drinking water. J. Am. Water Works Assoc. 81 (8) 41-53. https://doi.org/10.1002/j.1551-8833.1989.tb03258.x

KRASNER SW, WEINBERG HS and RICHARDSON SD (2006) Occurrence of a new generation of disinfection byproducts. Environ. Sci. Technol. 40 (23) 7175-7185. https://doi.org/10.1021/ es060353j

LIANG L and SINGER PC (2003) Factors influencing the formation and relative distribution of haloacetic acids and trihalomethanes in drinking water. Environ. Sci. Technol. 37 (13) 2920-2928. https:// doi.org/10.1021/es026230q

LI YH, WANG S and WEI J (2003) Adsorption of fluoride from water by aligned carbon nanotubes. Mater. Res. Bull. 38 469-476. https:// doi.org/10.1016/S0025-5408(02)01063-2

LI YH, DI ZC, DING J, WU DH, LUAN ZK and ZHU YQ (2005) Adsorption thermodynamic, kinetic and desorption studies of $\mathrm{Pb} 2+$ on carbon nanotubes. Water Res. 39 605-609. https://doi. org/10.1016/j.watres.2004.11.004

LIN DH and XING BS (2008) Adsorption of phenolic compounds by carbon nanotubes: role of aromaticity and substitution of hydroxyl groups. Environ. Sci. Technol. 42 7254-7259. https://doi. org/10.1021/es801297u

LOU JC, JUNG MJ, YANG HW, HAN JY and HUANG WH (2011) Removal of dissolved organic matter (DOM) from raw water by single-walled carbon nanotubes (SWCNTs). J. Environ. Sci. Health A 47 (10) 1478-1485. https://doi.org/10.1080/10934529.2011.606688

LU CS, CHUNG YL and CHANG KF (2005) Adsorption of trihalomethanes from water with carbon nanotubes. Water Res. 39 1183-1189. https://doi.org/10.1016/j.watres.2004.12.033

LU CY and CHIU HS (2006) Adsorption of zinc(II) from water with purified carbon nanotubes. Chem. Eng. Sci. 61 1138-1145. https:// doi.org/10.1016/j.ces.2005.08.007

LYN TL and TAYLOR JS (1993) Modeling compliance of chlorine residual and disinfection by-products. proceedings AWWA Water Quality Technology Conference, Miami, USA.

MA R and LU X (2012) Modeling of THMs and HAAs formation in distribution system upon chlorination. Adv. Mater. Res. 455-456 1273-1277. https://doi.org/10.4028/455-456.1273

MILLER JW and UDEN PC (1983) Characterization of aqueous chlorination products of humic substances. Environ. Sci. Technol. 17 150. https://doi.org/10.1021/es00018a022

MISHRA ND, DIXIT SC and SRIVASTAVA HC (2012) Evaluation of trihalomethane formation potential due to anthropogenic sources in the groundwater of Kanpur. J. Chem. 9 (2) 693-696. https://doi. org/10.1155/2012/280764

MISHRA BK, PRIYA T, GUPTA SK and SINHA A (2016) Modeling and characterization of natural organic matter and its relationship with the THMs formation. Global NEST J. 18 (4) 803-816.

NIKOLAOU AD, GOLFINOPOULOS SK, LEKKAS TD and KOSTOPOULOU MN (2004) DBP levels in chlorinated drinking water: effect of humic substances. Environ. Monit. Assess. 93 301-319. https://doi.org/10.1023/B:EMAS.0000016798.53163.43

NIKOLAOUA AD, GOLFINOPOULOS SK, ARHONDITSIS GB, KOLOVOYIANNIS V and LEKKAS TD (2004) Modeling the formation of chlorination by-products in river waters with different quality. Chemosphere 55 409-420. https://doi.org/10.1016/j. chemosphere.2003.11.008

NOVAK J, MILLS GL and BERTSCH PM (1992) Estimating the percent aromatic carbon in soil and aquatic humic substances using ultraviolet absorbance. J. Environ. Qual. 21 144. https://doi. org/10.2134/jeq1992.00472425002100010022x

ÖZDEMIR K, TORÖZ I and UYAK V (2013) Assessment of trihalomethane formation in chlorinated raw waters with 
differential UV spectroscopy approach. Sci. World J. 19 1-8. https:// doi.org/10.1155/2013/890854

ÖZDEMIR K (2014) Characterization of natural organic matter in conventional water treatment processes and evaluation of THM formation with chlorine. Sci. World J. 20 1-7. https://doi. org/10.1155/2014/703173

ÖZDEMIR K (2016) Experimental investigation of trihalomethanes removal in chlorinated drinking water sources with carbon nanomaterials. Fresenius Environ. Bull. 25 (12A), 6202-6214. https://doi.org/

PAN Y and ZHANG X (2013) Four groups of new aromatic halogenated disinfection byproducts: effect of bromide concentration on their formation and speciation in chlorinated drinking water. Environ. Sci. Technol. 47 (3) 1265-1273. https://doi. org/10.1021/es303729n

PLATIKANOV S, TAULER R, RODRIGUES PM, ANTUNES MC, PEREIRA D and ESTEVES DA SILVA JC (2010) Factorial analysis of the trihalomethane formation in the reaction of colloidal, hydrophobic, and transphilic fractions of DOM with free chlorine. Environ. Sci. Pollut. Res. 17 (8) 1389-1400. https://doi.org/10.1007/ s11356-010-0320-4

PONTIUS FD (1993) DBP rule to set tight standards. J. Am. Water Works Assoc. 85 22-30. https://doi.org/10.1002/j.1551-8833.1993. tb06095.x

POURMOGHADDAS H and STEVENS A (1995) Relationship between trihalomethanes and haloacetic acids with total organic halogen during chlorination. Water Res. 29 2059-2062. https://doi.org/10.10 16/0043-1354(95)00026-H

RECKHOW DA, SINGER PC and MALCOLM RL (1990) Chlorination of humic materials: byproduct formation and chemical interpretations. Environ. Sci. Technol. 24 1655-1664. https://doi. org/10.1021/es00081a005

RICHARDSON SD (1998) Encyclopaedia of Environmental Analysis and Remediation. Wiley, New York. 1398-1421.

ROCCARO P, VAGLIASINDI FGA and KORSHIN GV (2014) Relationships between trihalomethanes, haloacetic acids, and haloacetonitriles formed by the chlorination of raw, treated, and fractionated surface waters. J. Water Suppl. Res. Technol. 63 (1) 21-30. https://doi.org/10.2166/aqua.2013.043

ROCCARO P, KORSHIN GV, COOK D, CHOW CWK and DRIKAS $\mathrm{M}$ (2014) Effects of $\mathrm{pH}$ on the speciation coefficients in models of bromide influence on the formation of trihalomethanes and haloacetic acids. Water Res. 62 117-126. https://doi.org/10.1016/j. watres.2014.05.024

RODRIGUEZ MJ and SERODES JB (2001) Spatial and temporal evolution of trihalomethanes in three water distribution systems. Water Res. 35 1572-1586. https://doi.org/10.1016/ S0043-1354(00)00403-6

RONG H, GAO B and LI J (2013) Floc characterization and membrane fouling of polyferric-polymer dual/composite coagulants in coagulation/ultrafiltration hybrid process. J. Colloid Interf. Sci. 412 39-45. https://doi.org/10.1016/j.jcis.2013.09.013

ROOK JJ (1974) Formation of haloforms during chlorination of naturals waters. J. Water Treat. Exam. 23 234-243.

SADIQ R and RODRIGUEZ MJ (2004) Disinfection by-products (DBP) in drinking water and the predictive models for their occurrence: a review. Sci. Total Environ. 321 21-46. https://doi.org/10.1016/j. scitotenv.2003.05.001

SHARP EL, PARSONS SA and JEFFERSON B (2006) Impact of fractional character on coagulation with iron and aluminum salts Environ. Pollut. 140 (3) 436-443.

SHIH YH and LI MS (2008) Adsorption of selected volatile organic vapors on multiwall carbon nanotubes. J. Hazardous Mater. 154 21-28. https://doi.org/10.1016/j.jhazmat.2007.09.095

SINGER PC (1994) Control of disinfection by-products in drinking water. J. Environ. Eng. 120 727-744. https://doi.org/10.1061/ (ASCE)0733-9372(1994)120:4(727)

SHMEIS RMA, FAYYAD M and ALAWI M (2009) Predicting the formation of trihalomethanes and haloacetic acids in water treated with chlorine dioxide. Water Sci. Technol. 9 (4) 449-458. https:// doi.org/10.2166/ws.2009.563

SKETCHELL J, PETERSON HG and CHRISTOFI N (1995) Disinfection by-product formation after biologically assisted GAC treatment of water supplies with different bromide and DOC content. Water Res. 29 (12) 2635-2642. https://doi.org/10.1016/0043-1354(95)00130-D

KABSCH-KORBUTOWICZ M (2005) Application of ultrafiltration integrated with coagulation for improved NOM removal. Desalination 174 13-22. https://doi.org/10.1016/j.desal.2004.08.037 SOLARIK G, SUMMERS R, SOHN J, SWANSON WJ, CHOWDHURY ZK and AMY GL (2000) Extensions and verifications of the water treatment model for DBP formation. In: Barrett SE, Krasner SW and Amy GL (eds) Natural Organic Matter and Disinfection By-Products: Characterization and Control in Drinking Water. American Chemical Society Symposium Series Publication No. 761. American Chemical Society, Washington DC. 47-66.

STEVENS AA, MOORE LA and MILTNER RJ (1989) Formation and control of non-trihalomethane disinfection by-products. J. Am. Water Works Assoc. 81 (11) 54. https://doi. org/10.1002/j.1551-8833.1989.tb03259.x

TOROZ I and UYAK V (2005) Seasonal variation of trihalomethanes (THMs) within water distribution networks of Istanbul City. Desalination 17 127-141. https://doi.org/10.1016/j.desal.2004.11.008

TRINA SJ, NOVAK J and SMECK NE (1990) An ultraviolet absorbance method of estimating the percent aromatic carbon content in humic acids. J. Environ. Qual. 19 151. https://doi.org/10.2134/ jeq1990.00472425001900010023x

USEPA (United States Environmental Protection Agency) (1992) Methods for the Determination of Organic Compounds in Drinking Water - Supplement II. EPA - 600 /R-92/129. United States Environmental Protection Agency, Washington DC.

USEPA (United States Environmental Protection Agency) (2003) National primary drinking water regulations: stage 2 disinfectants and disinfection byproducts (D/DBP). Final Rule. vol. 68: 159.

UYAK V and TOROZ I (2005) Enhanced coagulation of disinfection by-products precursors in a main water supply of Istanbul. Environ. Technol. 26 261-266. https://doi.org/10.1080/09593332608618567

UYAK V, TOROZ I and MERIC S (2005) Monitoring and modeling of trihalomethanes (THM) for a water treatment plant in Istanbul. Desalination 176 91-101. https://doi.org/10.1016/j.desal.2004.10.023

UYAK V (2006) Multi-pathway risk assessment of trihalomethanes exposure in Istanbul drinking water supplies. Environ. Int. 32 212-221. https://doi.org/10.1016/j.envint.2005.03.005

UYAK V and TOROZ I (2006) Modeling the formation of chlorination by-products during enhanced coagulation. Environ. Monit. Assess. 121 503-517. https://doi.org/10.1007/s10661-005-9150-0

UYAK V, OZDEMIR K and TOROZ I (2007) Multiple linear regression modeling of disinfection by-products formation in Istanbul drinking water reservoirs. Sci. Total Environ. 378 (3) 269-280. https://doi.org/10.1016/j.scitotenv.2007.02.041

WANG XK, CHEN CL, HU WP, DING AP, XU D and ZHOU X (2005) Sorption of 243Am(III) to multiwall carbon nanotubes. Environ. Sci. Technol. 39 2856-2860. https://doi.org/10.1021/es048287d

WEI J, GAO B and YUE Q (2009) Comparison of coagulation behavior and floc structure characteristic of different polyferriccationic polymer dual-coagulants in humic acid solution. Water Res. 43 724-732. https://doi.org/10.1016/j.watres.2008.11.004

WHITE GC (1992) The Handbook of Chlorination and Alternative Disinfectants ( $3^{\text {rd }}$ edn). Van Nostrand Reinhold, New York.

WORRALL F and BURT TP (2009) Changes in DOC treatability: indications of compositional changes in DOC trends. J. Hydrol. 366 (1-4) 1-8. https://doi.org/10.1016/j.jhydrol.2008.11.044

YANG X, SHANG C and HUANG JC (2005) DPB formation in breakpoint chlorination of wastewater. Water Res. 39 (19) 4755 4767. https://doi.org/10.1016/j.watres.2005.08.033

YANG K, ZHU LZ and XING BS (2006) Adsorption of polycyclic aromatic hydrocarbons by carbon nanomaterials. Environ. Sci. Technol. 40 1855-1861. https://doi.org/10.1021/es052208w

YANG K, WU WH, JING QF and ZHU LZ (2008) Aqueous adsorption of aniline, phenol, and their substitutes by multi-walled carbon nanotubes. Environ. Sci. Technol. 42 7931-7936. https://doi. org/10.1021/es801463v

YOON Y, JOSEPH L, FLORA RVJ, SALEH H, BADAWY M and PARK YG (2012) Removal of natural organic matter from potential drinking water sources by combined coagulation and adsorption using carbon nanomaterials. Sep. Purif. Technol. 95 64-72. https:// doi.org/10.1016/j.seppur.2012.04.033

http://dx.doi.org/10.4314/wsa.v44i4.17

Available on website http://www.wrc.org.za

ISSN 1816-7950 (Online) = Water SA Vol. 44 No. 4 October 2018

Published under a Creative Commons Attribution Licence 
ZHANG Y, MARTINEZ D, COLLINS C, GRAHAM N, TEMPLETON MR, HUANG J and NIEUWENHUIJSEN M (2011) Modelling of haloacetic acid concentrations in a United Kingdom drinking water system. J. Water Supply Res. Technol. 60.5 275-285. https:// doi.org/10.2166/aqua.2011.047
ZHAO S, GAO B and WANG Y (2013) Influence of a new coagulant aid-enteromorpha extract on coagulation performance and floc characteristics of aluminum sulfate coagulant in kaolinhumic acid solution treatment. Colloids Surf. A. 417 161-169. https://doi. org/10.1016/j.colsurfa.2012.10.062 